\title{
Evaluation of Sodium Benzoate as a Preservative in Apple Juice after Different Periods of Storage in Sunlight on rats' Liver
}

\section{Elsayed ME Mahdy', Hanaa H Elsayed², Lamiaa M Mohamed³, Hoda A Abdel Salam $^{4}$ and Amira F Soliman ${ }^{5}$}

1. Biochemistry department - Faculty of science - Helwan University

2. Nutritional chemistry and metabolism department - National Nutrition Institute

3. Central health laboratories - Ministry of health

4. Field studies and survey department- National Nutrition Institute

5. Food science department - National Nutrition Institute

Corresponding author: Hanaa H Elsaysd, Email: Hanaa_Hamad2003@yahoo.com Mobil/ +02 01008825869

\section{SUMMARY}

reservatives boost food safety and expiration date by restricting microorganisms. It is considered xenobiotic; metabolism happens within the liver and may cause tissues inflammation and potential risk factors in the evolution of the various chronic ailments. This study was objective to inspect the effect of apple juice containing sodium benzoate (SB) after storage for 2 and 4 months within sunlight on rats' livers. In three storage stages: the juice containing $S B$ was estimated by high-performance liquid chromatography (HPLC) to limit $S B$ value. Ninety white male rats were distributed to three collections (10 rats/set): Normal, SB solution, and juice containing SB during the three storage stages for month/ stage. The biological evaluation like feed intake (FI) and rats' growth, biochemical factors "liver functions", biomarker oxidation in liver tissue such as glutathione reductase GSH and Malondialdehyde MDA, the liver histological examination were evaluated. The results were indicated that in the three storage stages, the FI and growth rates were significantly elevated within G2 compared to the healthy rats G1. Set 2 has the highest liver enzymes values during the assorted stages. The healthy group had the highest GSH and the lowest MDA value all period. The conclusion: SB has harmed the rats' livers in both groups, chemical solution SB and juice containing SB via the oxidation condition and liver enzymes.

Key words: Sodium benzoate, biomarker, rats' liver 


\section{INTRODUCTION}

Food preservatives improve the taste and texture of food by keeping its flavor and preventing it from spoiling (Helal et al., 2019). Naturals or chemicals preservatives substances can be used, the latest being the most successful in preserving foods for extended periods (Pongsavee, 2015). Koca and Karakahya (2016) reported that SB is a preservative present in foods having a $\mathrm{pH}$ below seven like salad sauce, juices, soft drinks, and jam, as well as appetizers. SB can inhibit the growth of fungi and bacteria and suppress the increased microbes, which causes food deterioration (Pongsavee, 2015).

SB is widely used in numerous industries because of this property, and it is an essential component of food, medicinal and cosmetic products (Mohamed and Saleh, 2019). SB affects the good physical condition of long-term consumers even at small concentrations and can cause headache, queasiness, vomit, inflammation of the mucous membrane of the nose, acute allergic, and excessively active in children. Induced injury at the molecular level, such as chromosomal damage for the liver, is also possible (Saatci et al., 2016). SB is aromatic components that are carcinogenic. It is digested with microorganisms' output energetic chemicals that interact with deoxyribonucleic acid (DNA) and change cell style (Gallo and colleagues 2020). SB can also affect alterations in gene expression by generating free radicals (Khan et al., 2020). The liver is the essential organ for several metabolic and detoxifying responses. It is critical to keep researching the negative impacts sodium benzoate may have on this main organ.

The goal of this study was to see how SB administration affect hepatic biologically and biochemically.

\section{MATERIALS AND METHODS}

\section{Materials:}

The chemicals and kits were obtained from El-Gomhorya Company for chemicals and drugs, Cairo, Egypt. Juice apple with preservative $\mathrm{SB}$ and corn oil required for preparing experimental diets purchased from 
local-market, Cairo, Egypt. Experimental animals: Ninety healthy adult male white rats "Sprague Dawley strain" were purchased from vaccine and immunity organization Helwan Farm, Cairo, Egypt. Standard diet was prepared according to Reeves et al., (1993).

\section{Methods:}

Storage of Juice:

Apple juice containing SB was exposed to sunlight for 2 and 4 months. Chemical analysis

Estimate of SB in apple juice at zero time and after two, 4 months storage within sunlight by HPLC according to Astuti et al., (2019). In that study, HighPerformance Liquid Chromatography (HPLC) method utilizing a Photodiode-Array Detection (PAD) detector was used for sodium benzoate levels analysis in fruit juice drinks. The mobile phase composition was methanol proHPLC: aqua pro admission (70:30) and added glacial acetic acid to reach $\mathrm{pH}$ 3. The analysis was conducted at a wavelength of 245 $\mathrm{nm}$, and the flow rate was set at $1.00 \mathrm{~mL} /$ minute.

\section{Biological experiment}

Ninety healthy adult male white rats "Sprague Dawley strain" confine single wire cages with wire bottoms under hygienic conditions. The diet was introduced to the rats in special food containers that avoid scattering of food. Additionally, water was provided to the rats by glass tube projection through the wire cages. Food and water were provided ad-libitum checked two times/week, and approved by the experimental animal unit in National Nutrition Institute.

\section{Experimental design}

The experiment was conducted in three stages of storage as follow:

- The first group (10 rats/ stage) received a basal diet with oral $5 \mathrm{ml}, 6.86$, and 7.7 distilled water / week, respectively / stage as a negative control group.

- The second group (10 rats/ stage) fed standard diet with oral 5, 6.86 and $7.7 \mathrm{ml}$ chemical SB solution / week respectively / stages concent-rate equal to that juice at zero time (1st 
Elsayed ME Mahdy, Hanaa H Elsayed, Lamiaa M Mohamed, Hoda A Abdel Salam and Amira F Soliman

stage); after two months (2nd stage) and four months (3rd stage) storage.

- The third group (10 rats/ stage) intake was a standard diet with oral 5, 6.86, and $7.7 \mathrm{ml}$ juice containing SB / week respectively at zero time (1st stage), after two months (2nd stage) and four months (3rd stage) storage according to acceptable range in juice $0.03-0.2 \%$ by volume (FDA, 1991).

At the end of each stage of the experimental period (4 weeks), the animals were sacrificed under anesthesia, and blood samples were collected in dry centrifuge tubes through retro-orbital injection. Additionally, the liver was removed from, which a portion was put in $10 \%$ formaldehyde to look at histopathology, and other part put at $-20^{\circ} \mathrm{c}$ to determine biomarker of oxidation. Serum kept in plastic vials at $-20^{\circ} \mathrm{c}$ until analysis.

\section{Biological evaluation}

Calculated feed intake (FI), growth rate

The amount of food left within the cage was subtracted from the quantity of food supplied to every animal daily to compute daily feed intake (FI; in grams) (Manjula and Krishna, 2016).

Throughout the experiment, the growth rate of rats altogether groups was measured weekly, and also the rate of growth for each group was as follows: Growth is that the difference between this weekly weight (g) and therefore the prior weekly weight (g) (Adeyemi and other, 2015)

\section{Biochemical assays}

Serum ALT and AST were determined by the method of Young, (2001). ALP level estimated "as explained by Tietz (1976)".

Liver tissue analyses, Malondialdehyde (MDA) measured in liver tissue according to Ohkawa et al. (1979). While the assay of GSH was performed using the spectrophotometric method (Goldberg and Spooner 1983).

\section{Histological examination}

The liver of each sacrificed rat was removed and fixed in a $10 \%$ neutral buffering formaldehyde solution with a $\mathrm{pH}$ of 7.5 , then cleaned in xylol before being fixed 
in paraffin. For histological analysis, a 4-5 $\mu \mathrm{m}$ thick piece was cut and spotted with Hematoxylin and Eosin (H\&E) (Bancroft and Gamble, 2008).

\section{Statistical Analysis}

The data assay was expressed as mean $\pm \mathrm{SD}$ and was analyzed by one-way analysis of variance (ANOVA) followed by a post hoc test. The difference was considered statistically significant when $\mathrm{P}<0.05$ (Chan, 2003).

\section{RESULTS AND DISCUSSION}

\section{Chemical analysis:}

Figure 1 displayed the sunlight exposure for two- or fourmonths storage period was caused diminish of SB value in apple juice, possibly losing quantity was converted to benzene. Santos et al., (2015) reported that the degradation of SB was a source of benzene within foodstuffs and carcinogenic to humans. This loss of SB may effect on shelf period of juice. McNeal et al., (1993) investigated the benzene formation from SB degradation with the presence of vitamin C. they applied watery models containing vitamin $\mathrm{C}$ and SB to evaluate the effect of temperature and UV on benzene formation. Who found that " 300 ng" benzene formed $/ \mathrm{ml}$ of aqueous solution stored at $45 \circ \mathrm{C}$ or under UV light for $20 \mathrm{~h}$. In addition, Aprea et al., (2008) researched the impact of the degree of heat present in solution on benzene formation utilizing the conformable vitamin $\mathrm{C}$ and SB concentrations in processed drinks. The aqueous was stored at $25 \circ \mathrm{C}, 45 \circ \mathrm{C}$ for $72 \mathrm{~h}$, benzene formation within the solution stored at $25 \circ \mathrm{C}$ remained fixed for the primary $12 \mathrm{~h}(<0.01$ $\mathrm{ppb)}$ but raised to $0.44 \mathrm{ppb}$ later $70 \mathrm{~h}$. The model solution stored at 45॰ C, $118.5 \mathrm{ppb}$ of benzene formed next $24 \mathrm{~h}$, amounting to $125 \mathrm{ppb}$ after $48 \mathrm{~h}$.

\section{Biological Effects of Sodium Benzoate:}

Figures $(2 \& \quad 3)$ were indicated the effect of SB administration on feed intake and growth at three storage stages. In the three storage stages, the FI and growth rates were significantly higher in set (2) than group (1). Set (3) had the highest FI and growth rate observed in Fig (1\&2). This is likely because apple juice includes sugar. These results are consistent 
with the findings of Olofinnade et al., (2021). SB has blocked leptin hormone release with adiposity model in vitro as a part of its immunological modulatory action according to Yilmaz and Karabay (2018), indicating the significance of SB to the evolution of obesity (Ciardi and colleagues, 2012).

\section{Biochemical factors:}

Figure 4 pointed for SB impacts on liver enzymes alanine aminotransferase (ALT), aspartate aminotransferase (AST), and alkaline phosphatase (ALP). The chemical SB (G2) was higher liver enzyme during the assorted stages than G3 that orally juice containing SB. These previous findings were in harmony with an investigation done by Ibekwe et al., (2007) through provided SB for two weeks makes major elevation within the values of AST and ALP. The excess values of AST are due to tissue necrosis in the liver, muscles, and cardiac tissues or elevated synthesis, lessening transaminase catabolism (Malik et al. 1980). Additionally, the elevation of several enzymes values "ALT and AST" in blood circulation be contingent on the range and variety of damage caused by a specific chemical (Weemhoff et al. 2017). The liver ailments caused by free radicals are characterized by a headway from degeneration of cells, inflamemation, and fibrous thickening of tissue, to cancer. An oversized of chemicals such as aromatic compounds (some food additives) are embroiled in the synthesis of reactive free radicals and tissue harm then enzymes are released from tissues (Aprioku 2013). Many varieties of food additives such as SB are found to provide the term of inflammation (Raposa et al. 2016). Some metabolites, which are formed due to partial reduction of oxygen like hydrogen peroxide $\left(\mathrm{H}_{2} \mathrm{O}_{2}\right)$, superoxide $\left(\mathrm{O}_{2}{ }^{-}\right)$and hydroxyl group $\left(\mathrm{OH}^{-}\right)$, are commonly known as free radicals. They are extremely toxic and cause oxidative stress at the cellular level with subsequent irregularities in metabolism. In most of the diseases such as metabolic syndrome, leukemia, obesity and liver disease, the free radicals have been observed to rise above normal level (Gutteridge and Halliwell, 1993). Free radical induced liver diseases are characterized by a progression from cirrhosis to hepatocellular 
malignancy. A large range of chemicals like aromatic compounds, pesticides, some food additives and ethanol are implicated in the generation of reactive free radicals and development of tissue damage (Aprioku 2013).

Biomarker of oxidation in tissue liver:

The effect of SB on oxidative liver state markers GSH and MDA value in different experimental groups were shown in Figure (5). The healthy group had the highest GSH and the lowest MDA value all over the experimental period. MDA of G3 < MDA of G2 and GSH value of G2 $<\quad$ G3. Imbalance among antioxidants and free radicals consequences fat oxidative. Malondialdehyde (MDA) is often an applied sign of lipid oxidation and it is an end metabolite of membrane cell peroxidation (Mansour 2000). Findings offered that oral intake of SB in juice or chemical solution has significantly increased MDA values. SB's existence with vitamin $\mathrm{c}$ in juice generates benzene, which has been considered carcinogenic and plays a significant role in different ailments by damaging impacts on deoxyribonucleic acid "DNA" (Gardner and Lawrence 1993). Reactive free radicals can be generated by metabolic outputs of SB. It increases oxidative stress at a cellular scale and is probable carcinogenic (Bansal et al., 2005). The antioxidant components within the cell including GSH are utilized to obviate cell harm by free radicals, thereby diminution their levels in the liver tissue until not give rise to hepatic suffering.

\section{Histologically alterations}

During storage, the liver of the healthy control group showed no histological alterations (as seen in Fig 6a, 6b\& 6c). While the liver of the group given apple juice containing SB was having undergone many histological changes during storage, including congestion of the portal vein and vacuolar degeneration of some hepatocytes (Fig 6g). Mild to moderate retraction of the necrotic changes (Fig 6h) particularly in the paracentral area after two months, and a good degree of restoration with degenerative and necrotic changes as focal areas limited (Fig $6 i)$, particularly in the per-portal 
areas after four months. Electron microscopy of G2 liver showed dilatation of central vein and congestion of portal vein with mild periportal edema and inflammatory cell infiltrations at zero time (Fig 6d). But after 2 months showed severe diffuse hepatocellular vacuolar degeneration with many necrotic and apoptotic cells (Fig 6e) and developed after 4 months to that the necrotic cells either appeared with nuclear remnants or without any nuclear structure, and the vacuolated cells appeared either with eccentric or pyknotic nuclei or without any nuclear structure (Fig 6f). These results may be attributed to the intake of $\mathrm{SB}$ in drinking water for four weeks causing histological changes in the liver tissues, as Khodaei and colleagues (2019) said. The majority of prior research found that the liver has been damaged histologically. Fujitani (1993) also mentio-ned swelling, bleeding, and the formation of syncytium in certain hepatocytes. The findings of Khodaei and colleagues (2019) suggested that the hepatotoxic effects of SB in longterm exposure could cause severe liver damage. Electron microscopy confirmed hepatocyte membrane injury, nuclear membrane degradation, and mitochondrial crista loss, as well as fusion in the outer membranes of mitochondria vacuolization, because of SB administration in organs and body (2442mg/kg body weight) for 10 days in rats (Bakar and Aktaç, 2014).

\section{CONCLUSION}

Sodium benzoate produces oxidative tension was low in the effectiveness of antioxidant enzymes and causing injury to interior tissues. In this study, the tissue damage was apparent by an excess of liver enzymes, histopathological alterations, and a slight increase in the final body weight in stages 2,3 . There were no significant differences among sets eaten juice containing SB and chemical solution of SB via the oxidation condition and liver function.

\section{REFERENCES:}

Adeyemi OT, Osilesi O, Adebawo OO, Onajobi FD and Oyedemi SO (2015):

Growth performance of weaned male albino rats fed 
on processed Atlantic horse mackerel (Trachurus trachurus). Growth, 30, 53-61.

Aprea E; Biasioli F; Carlin S; Mark TD and Gasperi F (2008):

"Monitoring benzene formation from benzoate in model systems by proton transfer reaction-mass spectrometry,"

International Journal of Mass Spectrometry, vol. 275 , no. 1-3, pp. 117-121.

\section{Aprioku JS (2013):}

Pharmacology of free radicals and the impact of reactive oxygen species on the testis. Journal of Reproduction \& Infertility, 14 (4), 158-172.

\section{Astuti EJ; Ilham RFN and} Rahman J (2019):

Validation method for determining sodium benzoate in fruit juice drinks in Malang. Farmasains: Juornal Farmasi danIlmu Kesehatan, 4(1), 19 -23.

Bakar E and Aktaç T (2014): Effects of sodium benzoate and citric acid on serum, liver and kidney tissue total sialic acid levels: An ultrastructural study. Journal of Applied Biological Sciences, 8(2), 09-15.

\section{Bancroft JD and Gamble $M$ (2008): \\ Theory and Practice of Histological Techniques. 6 th Edition, Churchill Livingstone, Elsevier, China.}

Bansal AK; Bansal M; Soni G and Bhatnagar D (2005):

Modulation of Nnitrosodiethylamine(NDE) induced oxidative stress by vitamin $\mathrm{E}$ in rat erythrocytes. Hum Exp Toxicol.; 24(6):297-302.

Chan YH (2003):

Biostatistics 102: quantitative data-parametric and non-parametric tests. Blood Press, 140(24.08), 79.

Ciardi C; Jenny M; Tschoner A; Ueberall F; Patsch J; Pedrini M and Fuchs D (2012):

Food additives such as sodium sulphite, sodium 
Elsayed ME Mahdy, Hanaa H Elsayed, Lamiaa M Mohamed, Hoda A Abdel Salam and Amira F Soliman

benzoate and curcumin inhibit leptin release in lipopolysaccharide-treated murine adipocytes in vitro. British journal of nutrition, 107(6), 826-833.

Food and Drug Administration "FDA" (1991):

Code of Federal Regulations. 7 CFR 52. Food products.

Fujitani T (1993):

Short-term effect of sodium benzoate in F344 rats and B6C3F1 mice. Toxicology letters, 69(2), 171-179.

Gallo M; Ferrara L; Calogero A; Montesano D and Naviglio D (2020):

Relationships between food and diseases: What to know to ensure food safety. Food Research International, 137, 109414.

\section{Gardner LK and Lawrence GD} (1993):

Benzene production from decarboxylation of benzoic acid in the presence of ascorbic acid and a transition-metal catalyst. Journal of Agricultural and Food Chemistry, 41(5), 693695.

\section{Goldberg DM and Spooner RJ} (1983):

Assay of Glutathione Reductase. In: Bergmeyen, H.V., Ed., Methods of Enzymatic Analysis, 3rd Edition, Vol. 3, Verlog Chemie, Deerfiled Beach, 258-265.

Helal EG; Abdelaziz MA and EL-Shenawe NS (2019):

Adverse Effects of Two Kinds of Food Additive Mixtures (Sodium benzoate+ Monosodium glutamate, Monosodium glutamate+ Chlorophyllin and Sodium benzoate+ Chlorophyllin) on Some Physiological Parameters in Male Albino Rats. The Egyptian Journal of Hospital Medicine, 75(4), 2736-2744.

Ibekwe SE; Uwakwe AA and Monanu MO (2007): 
Elsayed ME Mahdy, Hanaa H Elsayed, Lamiaa M Mohamed, Hoda A Abdel Salam and Amira F Soliman

In vivo effects of sodium benzoate on plasma aspartate amino transferase and alkaline phosphatase of wistar albino rats. Scientific Research and Essay, 2 (1), 10-12.

Koca YB and Karakahya $F$ (2016):

Effects of the food additive sodium benzoate on developing chicken liver. Cumhuriyet Üniversitesi Fen Edebiyat Fakültesi Fen Bilimleri Dergisi, 37(2), 8598.

Khan IS; Dar KB; Ganie SA and Ali MN (2020):

Toxicological impact of sodium benzoate on inflammatory cytokines, oxidative stress and biochemical markers in male Wistar rats. Drug and Chemical Toxicology, 1-10.

Khodaei F; Kholghipour H; Hosseinzadeh $M$ and Rashedinia M (2019):

Effect of sodium benzoate on liver and kidney lipid peroxidation and antioxidant enzymes in mice. Journal of Reports in Pharmaceutical

Sciences, 8(2), 217.

Malik JK; Singh RV; Gupta RC; Varman PN and Paul BS (1980):

Influence of fenitrothion on in vitro incorporation of acetate- $1-{ }^{14} \mathrm{C}$ in liver lipids and on various tissue enzymes in rats. Journal of Nuclear Agriculture and Biology, 9 (1), 25-28.

Manjula $K$ and Krishna $R$ (2016):

Feed efficiency and serobiochemical profile of wistar rats fed with spirulina as functional food. Current Research in Nutrition and Food Science Journal, 4(2), 135-140.

McNeal TP; Nyman PJ; Diachenko GW and Hollifield HC (1993):

"Survey of benzene in foods by using headspace concentration techniques and capillary gas 
chromatography," Journal of AOAC International, vol. 76, no. 6, pp. 1213-1219.

Mansour MA (2000):

Protective effects of thymoquinone and desferrioxamine against hepatotoxicity of carbon tetrachloride in mice. Life Sciences, 66 (26), 25832591.

\section{Mohamed NR and Saleh SA} (2019):

Effectiveness of Ginkgo Biloba Extract to Improve the Toxic Effects of Sodium Benzoate Administration in the Liver of Male Albino Mice. Research Journal of Pharmaceutical, Biological and Chemical Sciences, 10(5), 127-138.

\section{Ohkawa H; Ohishi N and Yagi K} (1979):

Assay for lipid peroxides in animal tissues by thiobarbituric acid reaction. Analytical biochemistry, 95(2), 351-358.

Olofinnade AT; Onaolapo AY and Onaolapo OJ (2021):
Anxiogenic, memory impairing, pro-oxidant and proinflamm-atory effects of sodium benzoate in the mouse brain. Dusunen Adam, 34(1), 14-22.

Pongsavee M (2015):

Effect of sodium benzoate preservative on micronucleus induction, chromosome break, and Ala 40Thr superoxide dismutase gene mutation in lymphocytes. BioMed research international: 1-5.

Raposa B; Pónusz R; Gerencsér G; Budán F; Gyöngyi Z; Tibold A; Hegyi D; Kiss I; Koller Á and Varjas T (2016):

Food additives: sodium benzoate, potassium sorbate, azorubine, and tartrazine modify the expression of $\mathrm{NFjB}$, GADD45a, and MAPK8 genes. Physiology International, 103 (3), 334343.

Reeves PG; Nielsen FH and Fahey GC (1993):

AIN-93 purified diets for laboratory rodents: Final 
report of the American Institute of Nutrition $\mathrm{Ad}$ Hoc Writing Committee on the Reformulation of the AIN-76A Rodent Diet. J. Nutr., 123(11): 1939-1951.

\section{Saatci C; Erdem Y; Bayramov} R; Akalın H; Tascioglu N and Ozkul Y (2016):

Effect of sodium benzoate on DNA breakage, micronucleus formation and mitotic index in peripheral blood of pregnant rats and their newborns. Biotechnology and Biotechnological Equipment, 30(6), 1179-1183.

\section{Santos VPS; Salgado AM;}

Torres AG and Pereira KS (2015):

Benzene as a Chemical Hazard in Processed Foods, International Journal of Food Science. Volume 2015, 7 pages.

Tietz NW (1976):
Fundamentals of clinical chemistry. WB Saunders Co., Philadelphia

Weemhoff JL; Woolbright BL; Jenkins RE; McGill MR; Sharpe MR; Olson JC; Antoine DJ Curry SC and Jaeschke $H$ (2017):

Plasma biomarkers to study mechanisms of liver injury in patients with hypoxic hepatitis. Liver Int. Official Journal of the International Association for the Study of the Liver, 37(3):377-384.

Yilmaz $B$ and Karabay AZ (2018):

Food Additive Sodium Benzoate $(\mathrm{NaB})$ Activates $\mathrm{NF} \kappa \mathrm{B}$ and Induces Apoptosis in HCT116 Cells. Molecules, 23(4), 723.

Young DS (2001):

Effects of disease on Clinical Lab. Tests, 4th ed AACC. 


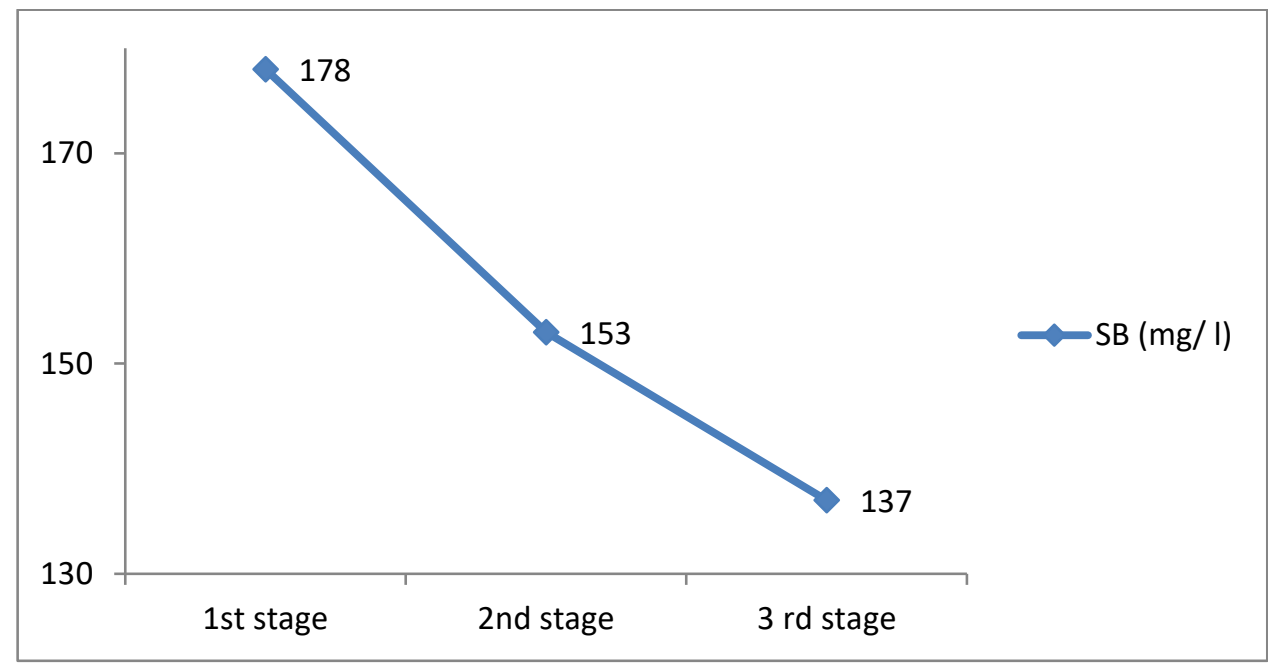

Fig. (1): Determination of SB (as benzoic acid) in apple juice by $H P L C ; L O Q=25 \mathrm{mg} / \mathrm{Kg}$. 


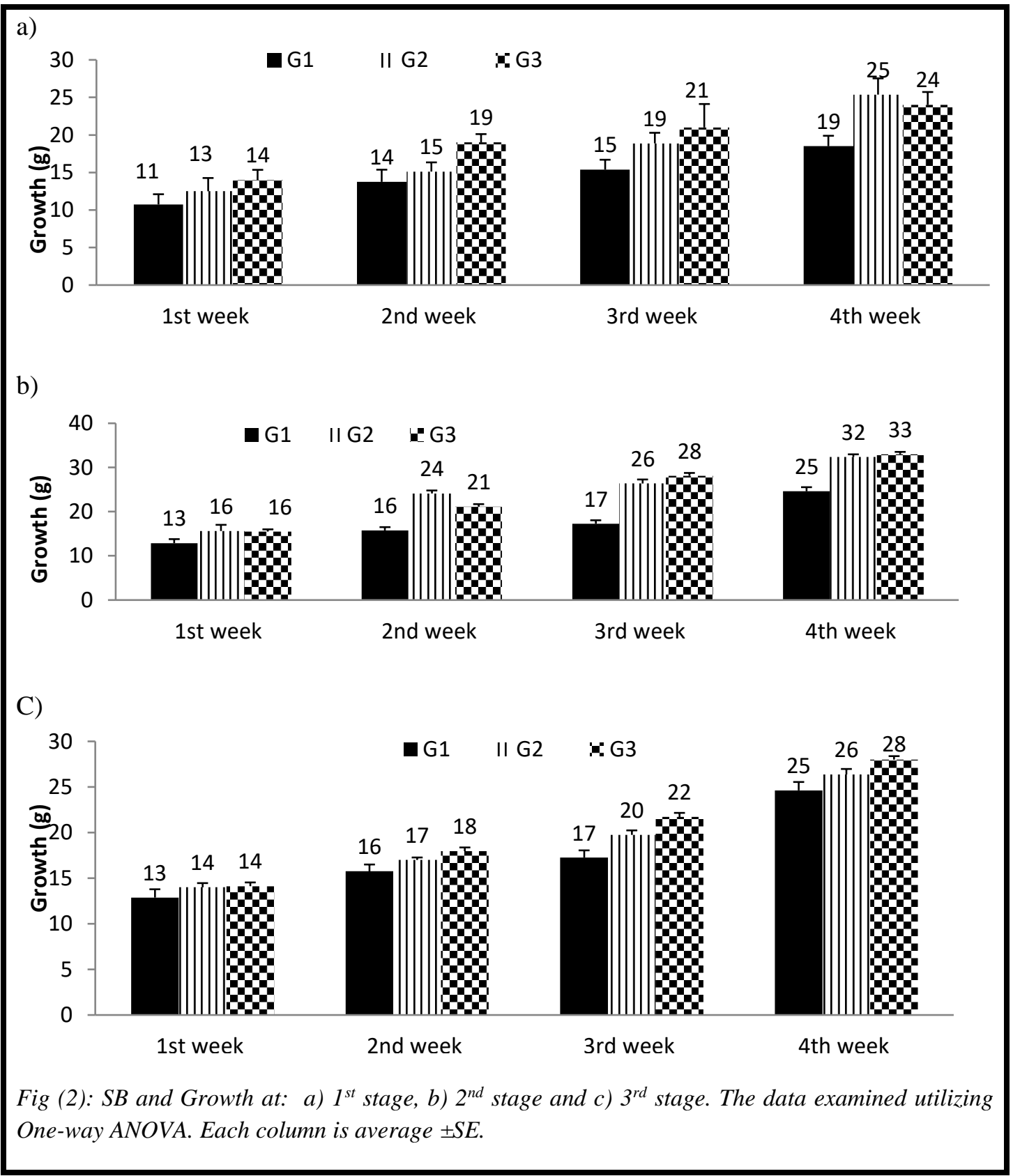

Bulletin of the National Nutrition Institute of the Arab Republic of Egypt. December 2020 (56) 147 
Evaluation the Role of Sodium Benzoate as a Preservative in Apple Juice after Different Periods of Storage in Sunlight on rats' Liver

Elsayed ME Mahdy, Hanaa H Elsayed, Lamiaa M Mohamed, Hoda A Abdel Salam and Amira F Soliman

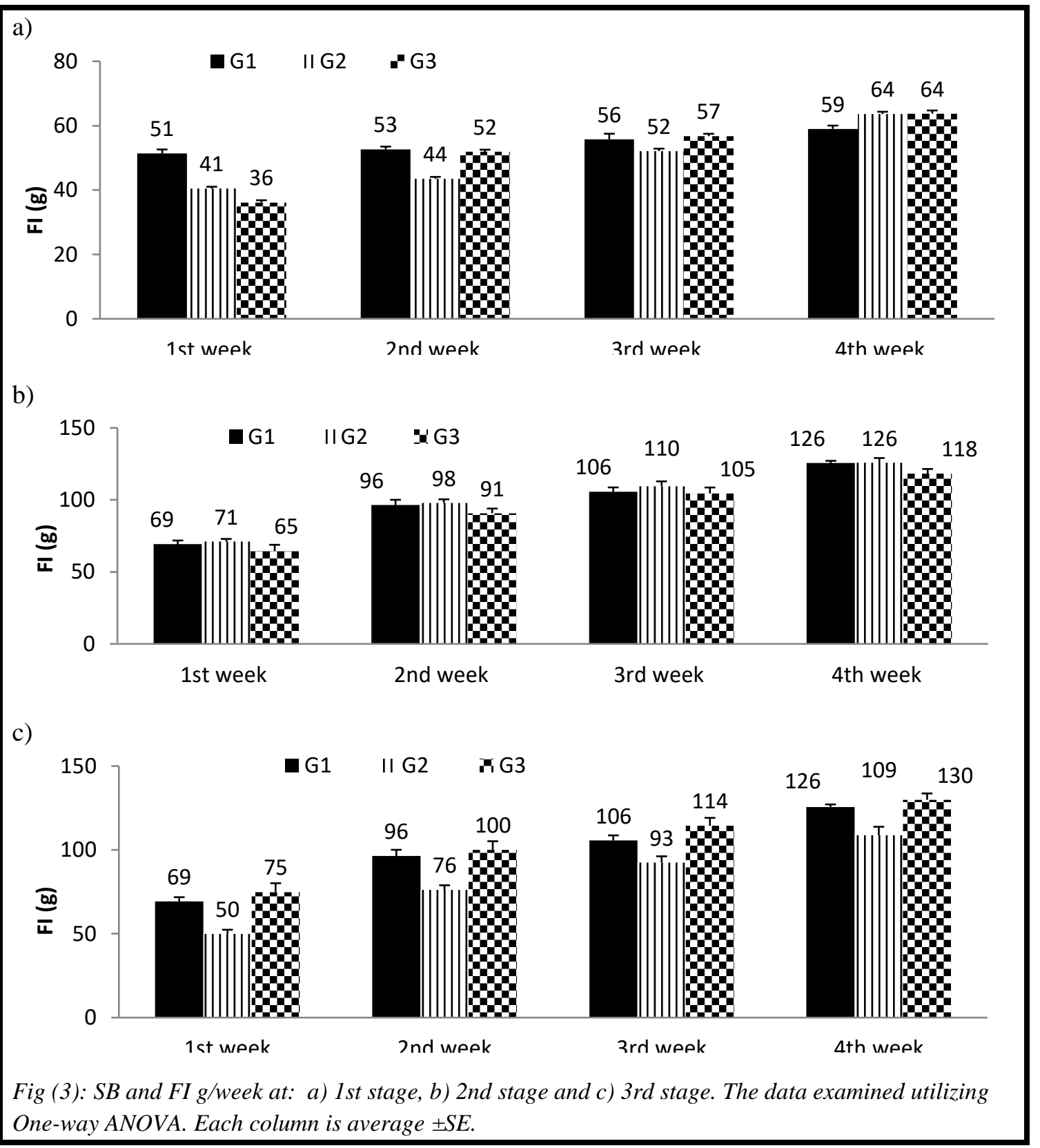

Bulletin of the National Nutrition Institute of the Arab Republic of Egypt. December 2020 (56) 148 


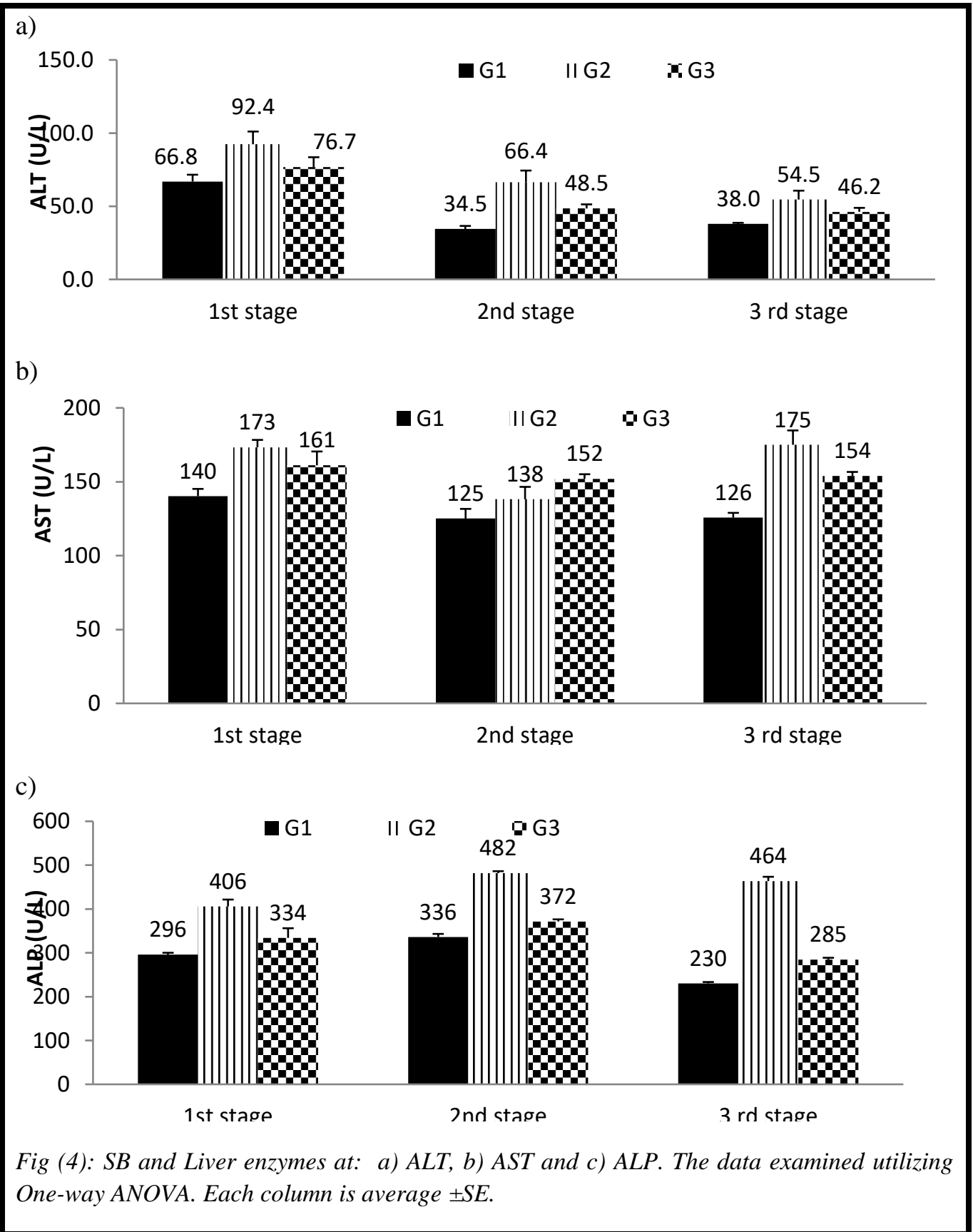

Bulletin of the National Nutrition Institute of the Arab Republic of Egypt. December 2020 (56) 149 


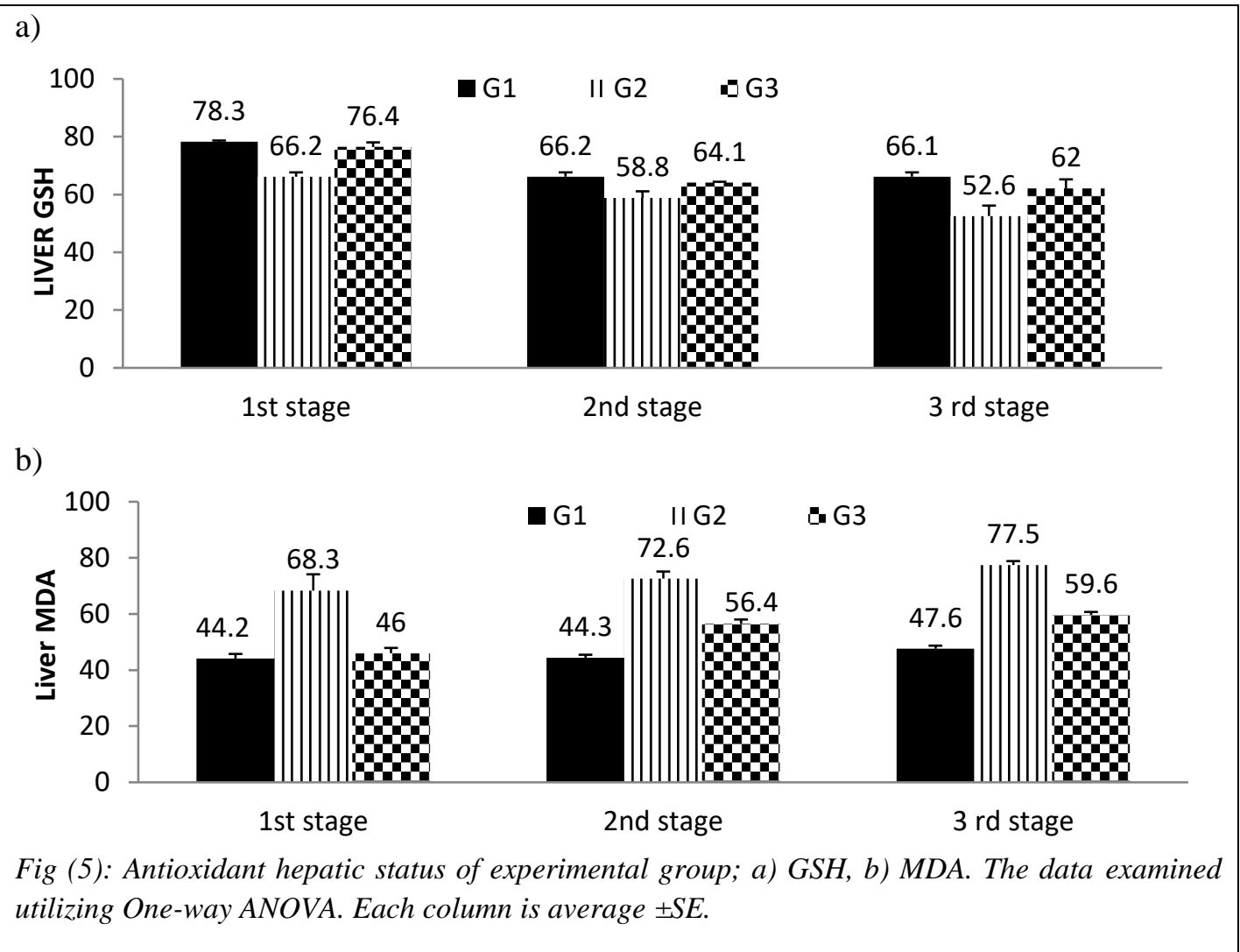

Bulletin of the National Nutrition Institute of the Arab Republic of Egypt. December 2020 (56) 150 
Evaluation the Role of Sodium Benzoate as a Preservative in Apple Juice after Different Periods of Storage in Sunlight on rats' Liver

Elsayed ME Mahdy, Hanaa H Elsayed, Lamiaa M Mohamed, Hoda A Abdel Salam and Amira F Soliman
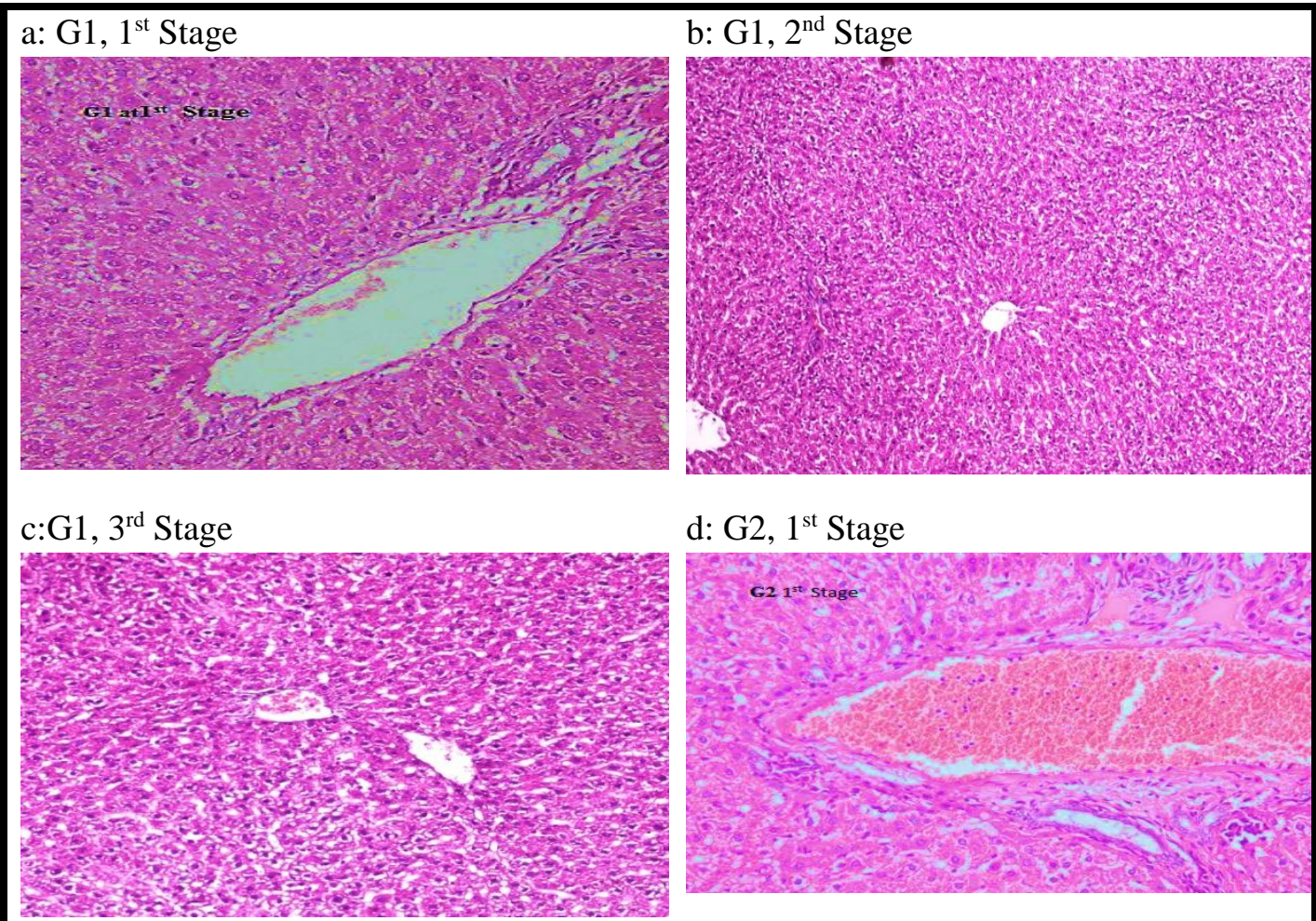

d: G2, $1^{\text {st }}$ Stage

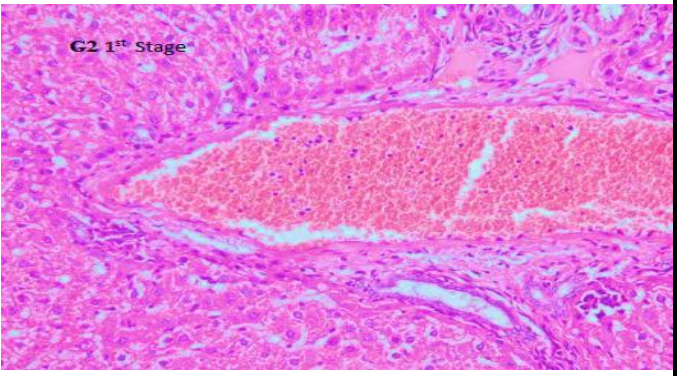

e: $\mathrm{G} 2,2^{\text {nd }}$ Stage

f:G2, $3^{\text {rd }}$ Stage
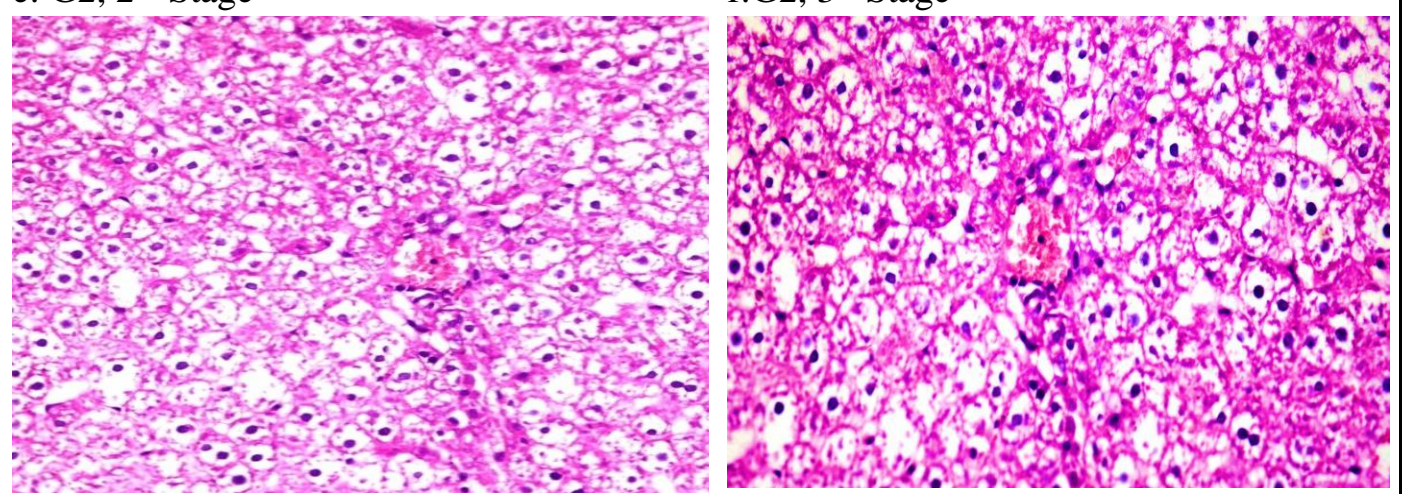

Bulletin of the National Nutrition Institute of the Arab Republic of Egypt. December 2020 (56) 151 


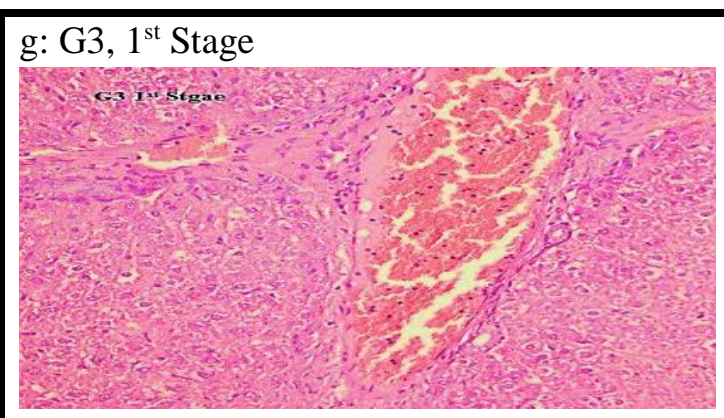

h: G3, $2^{\text {nd }}$ Stage

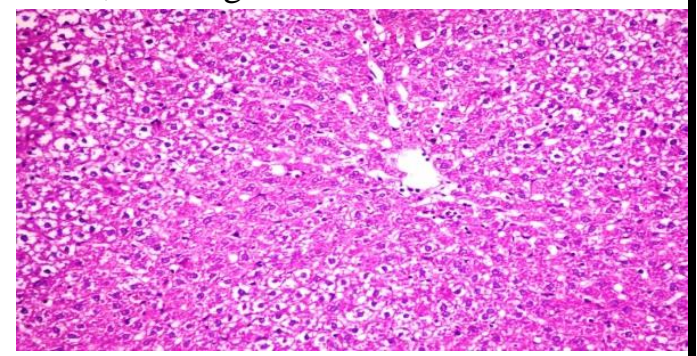

i: $\mathrm{G} 3,3^{\text {rd }}$ Stage

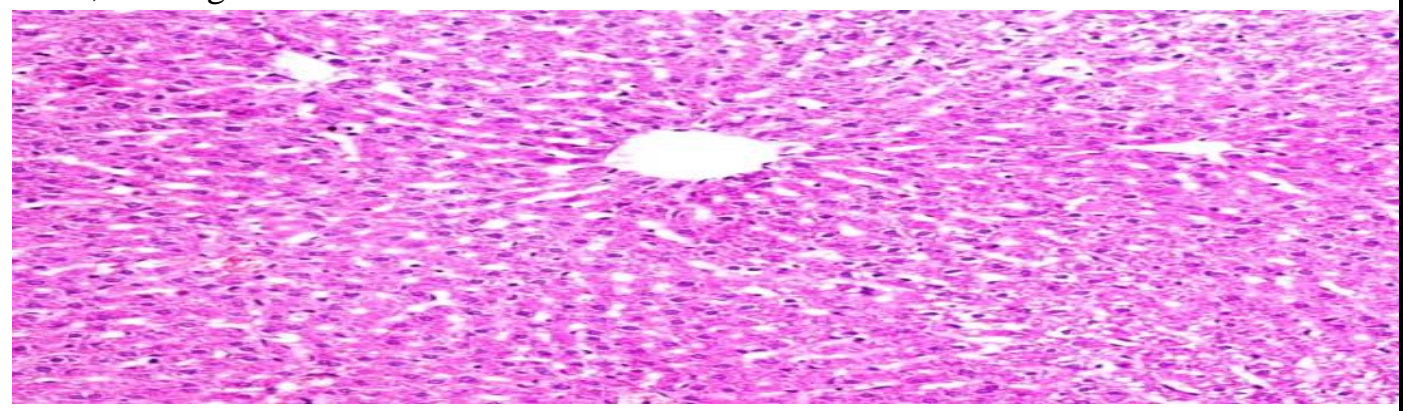

Fig. (6). TS of Liver of a),b) \&c) Normal control group showed normal histological structure d) G2 at $1^{\text {st }}$ Stage shows congestion of central veins and perioral fibrosis and inflammatory cells infiltration. e) G2 at $2^{\text {nd }}$ Stage showed severe diffuse hepatocellular vacuolar degeneration with many necrotic and apoptotic cells. ,f) G2 at $3^{\text {rd }}$ Stage the portal areas showed congested portal vessels and sometimes few mononuclear inflammatory cells infiltration. g) G3 at $1^{\text {st }}$ Stage shows congestion of portal vein, vacuolar degeneration of some hepatocytes. h) G3 at $2^{\text {nd }}$ Stage mild to moderate retraction of the necrobiosis changes but there is still hepatocellular vacuolar degeneration and necrosis. i) G3 at $3^{\text {rd }}$ Stage good degree of restoration of the hepatic parenchymal cells with limitation of degenerative and necrotic changes as focal areas.

Bulletin of the National Nutrition Institute of the Arab Republic of Egypt. December 2020 (56) 152 


\section{تقيم بنزوات الصوديوم كمادة حافظة في عصيز التفاح بعد فترات مختلفة من التخزين في ضوع الشمس على كبد الجرذان \\ السيا محمد مهدي1، هناء حسين السيد²، لمياء محمود محمد33، هلى عبد الرحمن عبد

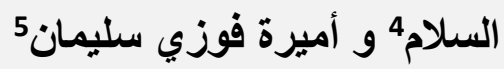

$$
\begin{aligned}
& \text { 1 }
\end{aligned}
$$

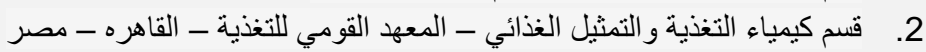

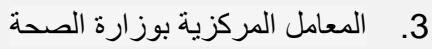

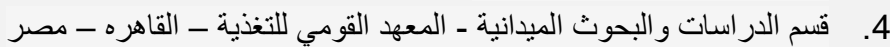

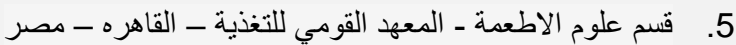

$$
\begin{aligned}
& \text { الملخص العربي }
\end{aligned}
$$

تعدل المواد الحافظة على تعزيز سلامة الغذاء وزيادة فترة الصلاحية عن طريق الحد من ندو الفبروسات والبكتبريا

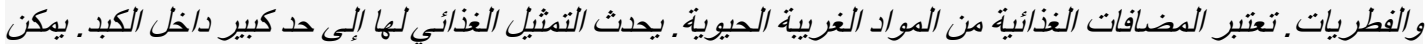

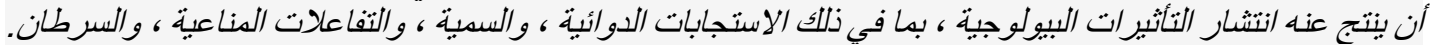

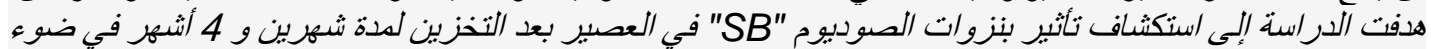

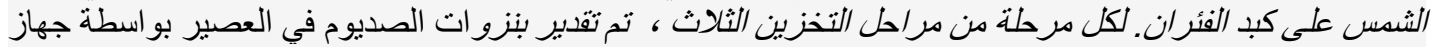

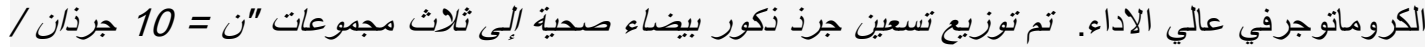

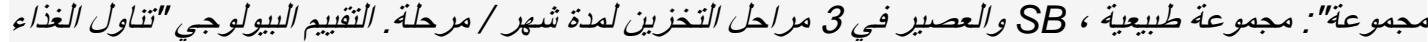

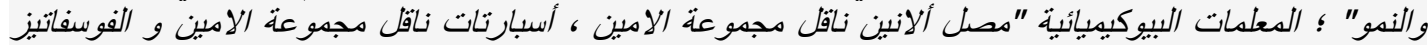

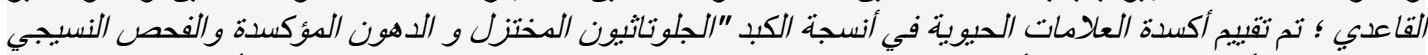

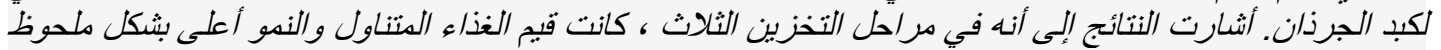

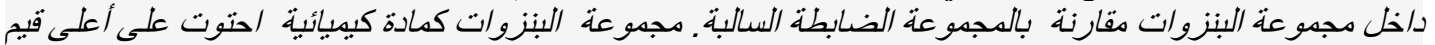

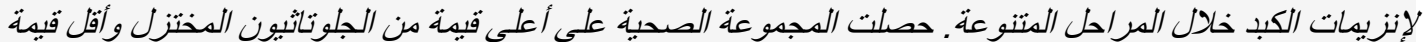
MوDA

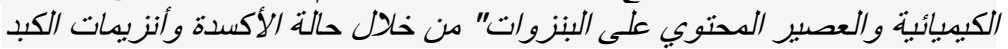

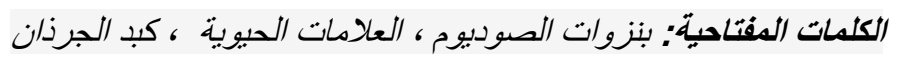

